\title{
ANALISIS POLA HUBUNGAN KERJA PONGGAWA SAWI PADA USAHA PERIKANAN TERIPANG DITINJAU DARI FUNGSI EKONOMI
}

\section{An Analysis of Work Relationship Pattern of Ponggawa Sawi in The Sea Cucumber Business In Terms of Economic Function}

\author{
*Naharuddin Sri dan Yusuf Kamlasi \\ Politeknik Pertanian Negeri Kupang \\ Jl. Adi Sucipto Penfui, P.O.Box. 1152, Kupang 85011 \\ "email: na_sry@yahoo.com \\ Diterima 23 April 2013 - Disetujui 6 Juni 2014
}

\begin{abstract}
ABSTRAK
Penelitian bertujuan untuk menganalisis pola hubungan kerja ponggawa sawi pada usaha perikanan teripang ditinjau dari fungsi ekonomitelah dilaksanakan pada Bulan April sampai Juni 2011 di Pulau Barrang Lompo, Kota Makassar. Metode penelitian yang digunakan adalah studi kasus dengan mewawancarai 8 orang ponggawa dan 45 orang sawi. Pengambilan sampel dilakukan secara Purposive Random Sampling. Analisis kualitatif digunakan untuk menganalisis pola hubungan kerja ponggawa sawi pada usaha perikanan teripang dan analisis kuantitatif untuk menganalisis pendapatan ponggawa dan sawi. Hasil penelitian menunjukkan adanya dua (2) pola hubungan kerja ponggawa sawi pada usaha perikanan teripang, yaitu berdasarkan suku dan kontrak kerja. Sistem bagi hasil ponggawa sawi pada usaha perikanan teripang ada dua (2) pola. Padapola pertamaponggawa mendapat bagian 25 persen dari hasil dan 75 persen dibagikan kepada sawi; sedangkan pada pola ke duaponggawa mendapat bagian 50 persen dari hasil dan 50 persen sisanya dibagikan kepada sawi. Pendapatan rata-rata per bulanponggawa pada sistem bagi hasil $25: 75$ berkisar Rp. 3.300 .000 sampai Rp. 4.500 .000 sedangkan sawiberkisar Rp. 750.000 sampai Rp. 1.375.000. Pada sistem bagi hasil 50 : 50, pendapatan ratarata per bulanponggawa berkisar Rp. 2.100.000,- sampai Rp. 2.980.000 dan sawi berkisar Rp. 480.000 sampai Rp. 1.650.000.
\end{abstract}

Kata Kunci: pola hubungan kerja, ponggawa sawi, perikanan teripang

\begin{abstract}
The study aimed to to analyze the ponggawa sawi workrelationship patternin the sea cucumberbusiness in terms of economic function was conducted April to June 2011 in Barrang Lompo Island, Makassar City. This was a case study involving 8 ponggawa and 45 sawi.Respondents were selected by purposive sampling. Qualitative analysis was used to analyse the work relationship patternof ponggawa sawi and quantitative analysis was used to analyzed ponggawa and sawi income. The study disclosed that there were two patterns of the work relationship in the sea cucumber business management: one was based on tribe and the other was based on work contract. There were two types of a profit shaing system. In type I, ponggawa had 25 percent of the share and sawi had 75 percent, while in type II, ponggawa has 50 percent and sawi had 50 percent. The average monthly incomes of ponggawa in the first system (25:75), respectively, was from IDR 750,000 to IDR 1,375,000 and sawi from IDR 3,300,000 to IDR 4,500,000. In the second system (50:50), the average monthly income of ponggawa and sawi respectively was IDR 2,100,000 to IDR 2,980,000 and IDR 480,000 to IDR 1,650,000.
\end{abstract}

Keywords: work relationship pattern, ponggawa sawi, sea cucumber business 


\section{PENDAHULUAN}

Masyarakat nelayan Indonesia sejak dahulu sudah memiliki pola hubungan kerjasama yang mendukung pelaksanaan aktifitasnya. Sistem hubungan kerja yang bersifat tradisional tersebut menjadi acuan dalam pengelolaan sumberdaya pesisir dan lautan, walaupun pemerintah telah membangun sistem pengelolaan modern. Menurut Indar (2005), sistem pengelolaan perikanan bersifat tradisional yang diperuntukkan masyarakat sampai saat ini diyakini masih digunakan oleh sebagian besar masyarakatnya, antara lain adalah sistem Sasi di Maluku, Panglima Laot di Aceh, Juragan Pandega di Jawa dan Ponggawa Sawi di Sulawesi Selatan.

Nelayan dalam menjalankan aktifitasnya menghadapi resiko, antara lain berupa resiko keselamatan di laut dan resiko ketidakpastian hasil tangkapan yang dapat diperoleh. Dalam menjalankan aktifitasnya, nelayan teripang membutuhkan sarana penangkapan seperti perahu, mesin, kompresor, masker dan kaki katak. Sarana tersebut tidak mampu dibeli oleh nelayan sawi. Upaya untuk mengatasi hal tersebut ditempuh dengan menjalin hubungan kerja dengan ponggawa. Kondisi ini selanjutnya menjadi titik awal terjalinnya hubungan kerja antara ponggawa dengan sawi pada usaha perikanan teripang, dimana mereka sepakat menjalin hubungan kerja karena masing-masing mempunyai tujuan yang ingin dicapai melalui hubungan tersebut.

Penelitian tentang ponggawasawi telah dilakukan oleh beberapa pakar, Sallatang (1982) mengkaji hubungan ponggawa sawi dari sudut pandang sosiologi dengan penekanan pada kelompok kecil dan Indar (2002) mengkaji hubungan ponggawa sawi dari sudut pandang pengelolaan pesisir dan laut. Para peneliti yang telah disebutkan sudah ada yang membicarakan ponggawa sawidari sudut pandang fungsi ekonomi, tetapi waktu pelaksanaan penelitiannya sudah lama sehingga kemungkinan sudah mengalami perubahan dalam hal sumber modal ponggawa, cara perekrutan sawi, lokasi penangkapan dan sistem bagi hasil. Khusus hubungan kerja ponggawa sawi pada usaha perikanan teripang, belum ada peneliti yang mengkajinya..

Hubungan kerja ponggawa sawi memiliki kecenderungan yang tampak timpang, dimana diasumsikan bahwa hubungan kerja tersebut lebih menguntungkan salah satu pihak. Untuk mengkaji ketimpangan hubungan kerja ponggawa-sawi, khususnya dari sudut pandang fungsi ekonomi dilakukan melalui pendekatan kerjasama operasi penangkapan, pembagian resiko dan distribusi pendapatan. Dari konteks inilah yang mendasari dan menarik perhatian penulis untuk melakukan penelitian tentang pola hubungan kerja ponggawa sawi pada usaha perikanan teripang ditinjau dari fungsi ekonomi. Penulis memilih usaha perikanan teripang karena pada usaha perikanan teripang terjalin hubungan kerja antara ponggawa dengan sawi, dimana ponggawa berperan sebagai pemilik sarana penangkapan, pemilik modal dan sawi yang mengoperasikannya, pada kerjasama produksi, terdapat pembagian kerja yaitu juragan laut, bas, penyelam, bagian selang dan koki yang berpengaruh pada pola hubungan kerja.

Berdasarkan latar belakang yang telah dikemukakan di atas, maka masalah yang berkaitan dengan penelitian ini adalah bagaimana pola hubungan kerja antara ponggawa sawi pada usaha perikanan teripang ditinjau dari fungsi ekonomi? Bagaimana bentuk sistem bagi hasil ponggawa sawi pada usaha perikanan teripang dan berapa besar pendapatan yang diterima ponggawa sawi berdasarkan pola hubungan kerja yang mereka jalin pada usaha perikanan teripang? Oleh karena itu, penelitian ini bertujuan untuk menganalisis pola hubungan kerja ponggawa sawi pada usaha perikanan teripang ditinjau dari fungsi ekonomi, menganalisis sistem bagi hasil ponggawa sawi pada usaha perikanan teripang dan menganalisis besar pendapatan yang diterima ponggawa sawi berdasarkan pola hubungan kerja yang mereka jalin pada usaha perikanan teripang.

\section{METODOLOGI}

Penelitian telah dilakukan di Pulau Barrang Lompo, Kecamatan Ujung Tanah Kota Makassar pada bulan April sampai Juni 2011. Pendekatan penelitian yang digunakan adalah pendekatan penelitian kualitatif dan kuantitatif. Pendekatan yang digunakan adalah pendekatan kualitatif dan kuantitatif. Pendekatan kualitatifuntuk menghasilkan data deskriptif mengenai kata-kata lisan maupun tulisan dan tingkah laku yang dapat diamati dari orang-orang yang diteliti untuk memberi gambaran yang lebih jelas tentang pola hubungan kerja ponggawa sawi pada usaha perikanan teripang di lokasi penelitian. Pendekatan kuantitatif untuk mengetahui jumlah pendapatan ponggawa sawi. Jenis penelitian yang digunakan adalah studi kasus 
(case study), yang merupakan bentuk penelitian yang mendalam tentang suatu aspek lingkungan, dalam hal ini pola hubungan kerja ponggawa sawi pada usaha perikanan teripang di lokasi penelitian.

Populasi obyek penelitian ini adalah semua ponggawa dan sawi pada usaha perikanan teripang yang ada di lokasi penelitian. Jumlah usaha perikanan teripang di lokasi penelitian sebanyak 15 usaha yang terdiri dari 15 ponggawa dan 150 sawi (Barrang Lompo dalam Angka, 2010). Teknik penarikan sampel ponggawa dan sawi dalam penelitian ini menggunakan Purposive Sampling, yaitu suatu proses penentuan sampel dengan pertimbangan tertentu dengan menentukan terlebih dahulu jumlah sampel yang hendak diambil, kemudian pemilihan sampel dilakukan dengan berdasarkan tujuan-tujuan tertentu (Sugiyono, 2008). Jumlah sampel ponggawa yang diambil dalam penelitian sebanyak 8 orang dan sawi sebanyak 45 orang. Jadi jumlah sampel ponggawa dan sawi telah memenuhi kriteria pengambilan sampel, yaitu minimal $10 \%$ dari jumlah populasi (Nasution, 2004).

Data yang dikumpulkan terdiri dari dua, yaitu data primer dan data sekunder. Data primer diperoleh dari hasil observasi, wawancara dan kuesioner. Sedangkan data sekunder diperoleh dari instansi pemerintah dan penelusuran pustaka. Metode pengambilan data lapangan meliputi observasi untuk memperoleh gambaran yang lebih jelas tentang kehidupan sosial ponggawa dan sawi di lokasi penelitian, khususnya mengenai pola hubungan kerja yang mereka jalin. Kuesioner merupakan instrumen pengumpulan data yang berfungsi debagai pedoman wawancara yang bertujuan untuk mendapatkan keterangan tentang fakta yang diketahui serta pendapat dan sikap responden yang dilakukan dengan cara memberi seperangkat pertanyaan tertulis kepada responden untuk dijawabnya. Pengisian kuesioner dilakukan dengan teknik wawancara terstruktur, yaitu sebagian pertanyaan dengan pilihan jawaban dan sebagian dengan pengisian. Kuesioner diberikan kepada responden yang ada di lokasi penelitian, yaitu ponggawa dan sawi untuk memperoleh informasi yang selanjutnya akan dipergunakan dalam menganalisis hubungan kerja antara ponggawa dengan sawi di lokasi penelitian. Diskusi mendalam dilakukan dengan responden ponggawa dan sawi untuk memperoleh informasi yang lebih terperinci tentang hubungan kerja yang terjalin antara ponggawa dengan sawi.
Untuk menjawab rumusan masalah dan tujuan penelitian, maka dilakukan analisis data kualitatif dan kuantitatif. Analisis kualitatif untuk menganalisis pola hubungan kerja ponggawa sawi pada usaha perikanan teripang, termasuk sistem bagi hasil dan besar pendapatan yang diterima ponggawa sawi. Sistem bagi hasil didasarkan pada Undang-undang Nomor 16 Tahun 1964 tentang bagi hasil perikanan, Pasal 3 ayat 1, jika suatu usaha parikanan diselenggarakan atas dasar perjanjian bagi-hasil, maka dari hasil usaha itu kepada pihak nelayan penggarap dan penggarap tambak paling sedikit harus diberikan bagian sebagai berikut: 1. perikanan laut: a. jika dipergunakan perahu layar: minimum $75 \%$ dari hasil bersih; b. jika dipergunakan kapal motor: minimum $40 \%$ ari hasil bersih. 2. Pembagian hasil diantara para nelayan penggarap dari bagian yang mereka terima menurut ketentuan dalam ayat 1 pasal ini diatur oleh mereka sendiri, dengan diawasi oleh Pemerintah Daerah Tingkat II yang bersangkutan untuk menghindarkan terjadinya pemerasan, dengan ketentuan, bahwa perbandingan antara bagian yang terbanyak dan yang paling sedikit tidak boleh lebih dari 3 lawan 1. Pasal 4. Angka bagian pihak nelayan penggarap dan penggarap tambak sebagai yang tercantum dalam pasal 3 ditetapkan dengan ketentuan, bahwa beban-beban yang bersangkutan dengan usaha perikanan itu harus dibagi sebagai berikut: 1. perikanan laut: a. beban-beban yang menjadi tanggungan bersama dari nelayan pemilik dan pihak nelayan penggarap: ongkos lelang, uang rokok/jajan dan biaya perbekalan untuk para nelayan penggarap selama di laut, biaya untuk sedekah laut (selamatan bersama) serta iuran-iuran yang disahkan oleh Pemerintah Daerah Tingkat II yang bersangkutan seperti untuk koperasi, dan pembangunan perahu/kapal, dana kesejahteraan, dana kematian dan lain-lainnya; b. beban-beban yang menjadi tanggungan nelayan pemilik: ongkos pemeliharaan dan perbaikan perahu/kapal serta alat-alat lain yang dipergunakan, penyusutan dan biaya eksploitasi usaha penangkapan, seperti untuk pembelian solar, minyak, es dan lain sebagainya.

Analisis kuantitatif digunakan untuk menganalisis biaya investasi dan biaya operasional yang dikeluarkan pada usaha perikanan teripang serta untuk menganalisis sitem bagi hasil sebagai dasar untuk mengetahui besar pendapatan ponggawa dan sawi. Rumus yang digunakan untuk analisis kuantitatif adalah:

- Penerimaan $=$ Jumlah hasil tangkapan $\mathbf{x}$ harga jual Pendapatan = Penerimaan - 
Biaya Total

- Selanjutnya pendapatan dibagi berdasarkan sistem bagi hasil Ponggawa sawi sehingga diperoleh nilai pendapatan ponggawa dan sawi.

\section{HASIL DAN PEMBAHASAN}

\section{Usaha Perikanan Teripang}

Investasi yang dikeluarkan oleh ponggawa sebagai pemilik usaha pada usaha perikanan teripang terdiri dari sarana penangkapan teripang. Sarana penangkapan yang digunakan terdiri dari kapal, mesin, kompressor, selang, gps, fishfinder, masker dan finch.

Untuk lebih jelasnya, jenis, jumlah dan harga sarana penangkapan teripang yang diinvestasikan ponggawa oleh pada usaha perikanan teripang di pulau Barrang Lompo dapat dilihat pada Tabel 1 berikut.
Tabel 1 menunjukkan, biaya investasi terbesar yang dikeluarkan oleh ponggawa pada usaha perikanan teripang adalah biaya pembelian kapal sekitar Rp. 30.000.000,- sampai Rp. 50.000.000,- dan mesin dengan harga sekitar Rp. 30.000.000,- sampai Rp. 60.000.000,-.

Hasil identifikasi terhadap responden ponggawa pada usaha perikanan teripang di Pulau Barrang Lompo menunjukkan bahwa jumlah biaya investasi ponggawa bervariasi. Distribusi responden ponggawa menurut biaya investasi yang dikeluarkan pada usaha perikanan teripang di pulau Barrang Lompo dapat dilihat pada Tabel 2.

Tabel 2 menunjukkan biaya investasi rata-rata yang dikeluarkan responden ponggawa sekitar Rp.158.300.000,- dengan kisaran Rp.125.200.000,- sampai Rp.192.200.000,-. Hal ini mengindikasikan bahwa untuk menjalankan usaha

Tabel 1. Jenis, Jumlah dan Harga Sarana Penangkapan yang Diinvestasikan oleh Ponggawa Pada Usaha Perikanan Teripang di Pulau Barrang Lompo, 2011.

Table 1.Type, Quantity and Price of Fishing Equipment Invested by Ponggawa in the Sea Cucumber (Holothuria Scabra) Business in Barrang Lompo Island, 2011.

\begin{tabular}{ccr}
\hline Jenis/Type & $\begin{array}{c}\text { Jumlah (Unit)/ } \\
\text { Quantity (Unit) }\end{array}$ & $\begin{array}{c}\text { Harga (Ribu Rupiah/unit)/ } \\
\text { Price (thousands of IDR/unit) }\end{array}$ \\
\hline Kapal/Boat & $1-2$ & $30,000-50,000$ \\
Mesin/Machine & 2 & $30,000-60,000$ \\
Kompressor/Compressor & $1-2$ & $6,000-10,000$ \\
Selang/hose & $1-2$ & $750-1,000$ \\
GPS & 1 & 1,000 \\
Fishfinder & 1 & $5,000-6,000$ \\
Masker/Mask & 2 & $350-500$ \\
Kaki katak/Finch) & 2 & $500-750$ \\
\hline
\end{tabular}

Sumber : Data primer setelah diolah (2011)/Source : Primary data processed (2011)

Tabel 2. Biaya Investasi yang Dikeluarkan oleh Ponggawa Perkapal Pada Usaha Perikanan Teripang di Pulau Barrang Lompo, 2011.

Table 2. Investment Cost Incurred by Ponggawa in the Sea Cucumber (Holothuria Scabra) Business at Barrang Lompo Island, 2011.

\begin{tabular}{|c|c|}
\hline $\begin{array}{c}\text { Usaha Perikanan Responden Ponggawa/ } \\
\text { Fishery Business Respondents }\end{array}$ & $\begin{array}{c}\text { Total Biaya Investasi (Ribu Rupiah)/ } \\
\text { Total Investment Cost (Thousands of IDR, }\end{array}$ \\
\hline . & 192,200 \\
\hline 2 & 180,200 \\
\hline 3 & 182,500 \\
\hline 4 & 183,700 \\
\hline 5 & 130,200 \\
\hline 6 & 125,200 \\
\hline 7 & 130,200 \\
\hline 8 & 142,200 \\
\hline Jumlah/Total & $1,266,400$ \\
\hline Rata-rata/Average & 158,300 \\
\hline Kisaran/Range & $125,200 \mathrm{~s} / \mathrm{d} 192,200$ \\
\hline
\end{tabular}

Sumber : Data primer setelah diolah (2011)/Source : Primary data processed (2011) 
perikanan teripang diperlukan investasi yang besar. Oleh karena itu, skala usaha perikanan teripang sangat bergantung dari jumlah modal yang dimiliki oleh ponggawa.

Berdasarkan hasil penelitian di Pulau Barrang Lompo, diketahui bahwa jenis biaya operasional yang dikeluarkan pada usaha perikanan teripang terdiri dari biaya bahan bakar, air tawar, bahan pengawet, konsumsi sawi selama operasi penangkapan dan biaya lain-lain.

Distribusi rata-rata biaya operasional tiap kapal yang dikeluarkan per trip pada operasi penangkapan teripang berdasarkan lokasi penangkapan pada usaha perikanan teripang di Pulau Barrang Lompo dapat dilihat pada Tabel 3 berikut.

Tabel 3 menunjukkan biaya operasional rata-rata perkapal setiap trip yang dikeluarkan responden ponggawa untuk lokasi penangkapan di perairan Balikpapan rata-rata sekitar Rp. 21.002.500,- dengan kisaran Rp. 17.725.000,- sampai Rp. 24.390.000,-, perairan Banjarmasin rata-rata sekitar Rp. 27.488.000,- dengan kisaran Rp. 22.815.000,- sampai Rp.32.460.000,- dan perairan Mamuju rata-rata sekitar Rp. 9.213.750,dengan kisaran Rp. 8.550.000,- sampai Rp. 26.000.000,- .

Distribusi rata-rata biaya operasional tara-rata per tahun tiap kapal berdasarkan lokasi penangkapan pada usaha perikanan teripang di pulau Barrang Lompo dapat dilihat pada Tabel 4.

Tabel 4 menunjukkan biaya operasional rata-rata per tahun setiap kapal yang dikeluarkan responden ponggawa untuk lokasi penangkapan di perairan Balikpapan rata-rata sekitar Rp. 63.007.500,- dengan kisaran Rp. 53.175.000,sampai Rp. 73.170.000,-, perairan Banjarmasin rata-rata sekitar Rp27.488.000,- dengan kisaran Rp. 22.815.000,- sampai Rp. 32.460.000,- dan perairan Mamuju rata-rata sekitar Rp. 18.427.500,dengan kisaran Rp. 17.100.000,- sampai Rp. 19.850.000,-. Hal ini mengindikasikan bahwa

Tabel 3. Biaya Operasional Rata-Rata Per Trip Tiap Kapal Berdasarkan Lokasi Penangkapan Pada Usaha Perikanan Teripang di Pulau Barrang Lompo, 2011.

Table 3. Average Operating Costs of Each Boat Trip According to Fishing Ground in The Sea Cucumber (Holothuria Scabra) Business in Barrang Lompo Island, 2011.

\begin{tabular}{|c|c|c|c|c|c|c|}
\hline $\begin{array}{l}\text { Responden/ } \\
\text { Respondent }\end{array}$ & $\begin{array}{l}\text { Lokasi/ } \\
\text { Location }\end{array}$ & $\begin{array}{c}\text { Biaya } \\
\text { Operasional } \\
\text { (Ribu } \\
\text { Rupiah)/ } \\
\text { Operational } \\
\text { Cost } \\
\text { (Thousands } \\
\text { of IDR) }\end{array}$ & $\begin{array}{l}\text { Lokasi/ } \\
\text { Location }\end{array}$ & $\begin{array}{c}\text { Biaya } \\
\text { Operasional } \\
\text { (Ribu } \\
\text { Rupiah)/ } \\
\text { Operational } \\
\text { Cost } \\
\text { (Thousands } \\
\text { of IDR) }\end{array}$ & $\begin{array}{l}\text { Lokasi/ } \\
\text { Location }\end{array}$ & $\begin{array}{c}\text { Biaya } \\
\text { Operasional } \\
\text { (Ribu Rupiah)/ } \\
\text { Operational } \\
\text { Cost } \\
\text { (Thousands of } \\
\text { IDR) }\end{array}$ \\
\hline 1 & $\begin{array}{l}\text { Perairan } \\
\text { B.papan }\end{array}$ & 23,350 & $\begin{array}{l}\text { Perairan } \\
\text { B.Masin }\end{array}$ & 31,350 & $\begin{array}{l}\text { Perairan } \\
\text { Mamuju }\end{array}$ & 9,925 \\
\hline 2 & $\begin{array}{l}\text { Perairan } \\
\text { B.papan }\end{array}$ & 23,370 & $\begin{array}{l}\text { Perairan } \\
\text { B.Masin }\end{array}$ & 31,430 & $\begin{array}{l}\text { Perairan } \\
\text { Mamuju }\end{array}$ & 8,950 \\
\hline 3 & $\begin{array}{l}\text { Perairan } \\
\text { B.papan }\end{array}$ & 24,390 & $\begin{array}{l}\text { Perairan } \\
\text { B.Masin }\end{array}$ & 32,460 & $\begin{array}{l}\text { Perairan } \\
\text { Mamuju }\end{array}$ & 8,550 \\
\hline 4 & $\begin{array}{l}\text { Perairan } \\
\text { B.papan }\end{array}$ & 23,360 & $\begin{array}{l}\text { Perairan } \\
\text { B.Masin }\end{array}$ & 31,410 & $\begin{array}{l}\text { Perairan } \\
\text { Mamuju }\end{array}$ & 9,430 \\
\hline 5 & $\begin{array}{l}\text { Perairan } \\
\text { B.papan }\end{array}$ & 18,775 & $\begin{array}{l}\text { Perairan } \\
\text { B.Masin }\end{array}$ & 23,312 & $\begin{array}{l}\text { Perairan } \\
\text { Mamuju }\end{array}$ & - \\
\hline 6 & $\begin{array}{l}\text { Perairan } \\
\text { B.papan }\end{array}$ & 17,725 & $\begin{array}{l}\text { Perairan } \\
\text { B.Masin }\end{array}$ & 22,815 & $\begin{array}{l}\text { Perairan } \\
\text { Mamuju }\end{array}$ & - \\
\hline 7 & $\begin{array}{l}\text { Perairan } \\
\text { B.papan }\end{array}$ & 18,775 & $\begin{array}{l}\text { Perairan } \\
\text { B.Masin }\end{array}$ & 23,312 & $\begin{array}{l}\text { Perairan } \\
\text { Mamuju }\end{array}$ & - \\
\hline 8 & $\begin{array}{l}\text { Perairan } \\
\text { B.papan }\end{array}$ & 18,275 & $\begin{array}{l}\text { Perairan } \\
\text { B.Masin }\end{array}$ & 23,815 & $\begin{array}{l}\text { Perairan } \\
\text { Mamuju }\end{array}$ & - \\
\hline Jumlah/Total & & 168,020 & & 219,904 & & 36,855 \\
\hline $\begin{array}{l}\text { Rata-rata/ } \\
\text { Average }\end{array}$ & & $21,002.5$ & & 27,488 & & $9,213.75$ \\
\hline Kisaran/Range & & $\begin{array}{r}17,725 \mathrm{~s} / \mathrm{d} \\
24,390 \\
\end{array}$ & & $\begin{array}{r}22,815 / d \\
32,460 \\
\end{array}$ & & $\begin{array}{c}8,550 \mathrm{~s} / \mathrm{d} \\
26,000\end{array}$ \\
\hline
\end{tabular}

Sumber : Data primer setelah diolah (2011)/Source : Primary data processed (2011) 
Tabel 4. Biaya Operasional Rata-Rata Per Tahun Tiap Kapal Per Trip Berdasarkan Lokasi Penangkapan Pada Usaha Perikanan Teripang di Pulau Barrang Lompo, 2011.

Table 4. Average Operating Costs of Each Boat Trip According to Fishing Ground in The Sea Cucumber (Holothuria Scabra) Business in Barrang Lompo Island, 2011.

\begin{tabular}{|c|c|c|c|c|c|c|}
\hline $\begin{array}{l}\text { Responden/ } \\
\text { Respondent }\end{array}$ & $\begin{array}{l}\text { Lokasi/ } \\
\text { Location }\end{array}$ & $\begin{array}{c}\text { Biaya } \\
\text { Operasional } \\
\text { (Ribu Rupiah)/ } \\
\text { Operational } \\
\text { Cost } \\
\text { (Thousands of } \\
\text { IDR) }\end{array}$ & $\begin{array}{l}\text { Lokasi/ } \\
\text { Location }\end{array}$ & $\begin{array}{c}\text { Biaya } \\
\text { Operasional } \\
\text { (Ribu } \\
\text { Rupiah)/ } \\
\text { Operational } \\
\text { Cost } \\
\text { (Thousands } \\
\text { of IDR) }\end{array}$ & $\begin{array}{l}\text { Lokasi/ } \\
\text { Location }\end{array}$ & $\begin{array}{c}\text { Biaya } \\
\text { Operasional } \\
\text { (Ribu } \\
\text { Rupiah)/ } \\
\text { Operational } \\
\text { Cost } \\
\text { ( Thousands } \\
\text { of IDR) }\end{array}$ \\
\hline 1 & $\begin{array}{l}\text { Perairan } \\
\text { B.papan }\end{array}$ & 70,050 & $\begin{array}{c}\text { Perairan } \\
\text { B.Masin }\end{array}$ & 31,350 & $\begin{array}{l}\text { Perairan } \\
\text { Mamuju }\end{array}$ & 19,850 \\
\hline 2 & $\begin{array}{l}\text { Perairan } \\
\text { B.papan }\end{array}$ & 70,110 & $\begin{array}{l}\text { Perairan } \\
\text { B.Masin }\end{array}$ & 31,430 & $\begin{array}{l}\text { Perairan } \\
\text { Mamuju }\end{array}$ & 17,900 \\
\hline 3 & $\begin{array}{l}\text { Perairan } \\
\text { B.papan }\end{array}$ & 73,170 & $\begin{array}{l}\text { Perairan } \\
\text { B.Masin }\end{array}$ & 32,460 & $\begin{array}{l}\text { Perairan } \\
\text { Mamuju }\end{array}$ & 17,100 \\
\hline 4 & $\begin{array}{l}\text { Perairan } \\
\text { B.papan }\end{array}$ & 70,080 & $\begin{array}{l}\text { Perairan } \\
\text { B.Masin }\end{array}$ & 31,410 & $\begin{array}{l}\text { Perairan } \\
\text { Mamuju }\end{array}$ & 18,860 \\
\hline 5 & $\begin{array}{l}\text { Perairan } \\
\text { B.papan }\end{array}$ & 56,325 & $\begin{array}{l}\text { Perairan } \\
\text { B.Masin }\end{array}$ & 23,312 & $\begin{array}{l}\text { Perairan } \\
\text { Mamuju }\end{array}$ & - \\
\hline 6 & $\begin{array}{l}\text { Perairan } \\
\text { B.papan }\end{array}$ & 53,175 & $\begin{array}{l}\text { Perairan } \\
\text { B.Masin }\end{array}$ & 22,815 & $\begin{array}{l}\text { Perairan } \\
\text { Mamuju }\end{array}$ & - \\
\hline 7 & $\begin{array}{l}\text { Perairan } \\
\text { B.papan }\end{array}$ & 56,325 & $\begin{array}{l}\text { Perairan } \\
\text { B.Masin }\end{array}$ & 23,312 & $\begin{array}{l}\text { Perairan } \\
\text { Mamuju }\end{array}$ & - \\
\hline 8 & $\begin{array}{l}\text { Perairan } \\
\text { B.papan }\end{array}$ & 54,825 & $\begin{array}{l}\text { Perairan } \\
\text { B.Masin }\end{array}$ & 23,815 & $\begin{array}{l}\text { Perairan } \\
\text { Mamuju }\end{array}$ & - \\
\hline Jumlah/Total & & 504,060 & & 219,904 & & 73,710 \\
\hline $\begin{array}{l}\text { Rata-rata/ } \\
\text { Average }\end{array}$ & & $63,007.5$ & & 27,488 & & $18,427.5$ \\
\hline Kisaran/Range & & $\begin{array}{r}53,175 \mathrm{~s} / \mathrm{d} \\
73,170 \\
\end{array}$ & & $\begin{array}{r}22,815 \mathrm{~s} / \mathrm{d} \\
32,460 \\
\end{array}$ & & $\begin{array}{r}17,100 \mathrm{~s} / \mathrm{d} \\
19,850 \\
\end{array}$ \\
\hline
\end{tabular}

Sumber : Data primer setelah diolah (2011)/Source : Primary data processed (2011)

jarak lokasi dan lama operasi penangkapan teripang mempengaruhi jumlah biaya operasional. Selain itu, biaya operasional penangkapan teripang juga dipengaruhi oleh ukuran kapal, besar mesin dan jumlah sawi.

Biaya operasional yang dikeluarkan untuk operasi penangkapan umumnya ditanggung oleh ponggawa, tetapi jika operasi penangkapan mengalami kerugian, maka kerugiannya harus ditanggung bersama oleh para sawi sebagai konsekuensi. Apabila sawi belum memiliki dana untuk menutupi kerugian, maka besar kerugian tersebut dikategorikan sebagai utang oleh ponggawa. Hal ini yang menjadi salah satu kendala yang dihadapi sawi dalam mengakumulasi kapital, sehingga kehidupannya tetap berada dalam kemiskinan.

Berdasarkan hasil penelitian diketahui bahwa di Pulau Barrang Lompo tidak semua biaya operasional penangkapan teripang ditanggung oleh ponggawa, tetapi ada juga sawi yang menanggung biaya operasional penangkapan teripang dengan cara patungan sesama sawi. Hal ini mereka lakukan untuk mengantisipasi resiko penambahan utang jika operasi penangkapan teripang mengalami kerugian.

Jenis biaya tetap yang dikeluarkan setiap tahun pada usaha perikanan teripang terdiri dari total biaya penyusutan kapal, mesin, kompressor, selang, gps, fishfinder, masker dan kaki katak ditambah pajak. Distribusi responden ponggawa menurut biaya tetap yang dikeluarkan perkapal pada usaha perikanan teripang di pulau Barrang Lompo dapat dilihat pada Tabel 5.

Tabel 5 menunjukkan biaya tetap rata-rata yang dikeluarkan responden ponggawa sekitar Rp 29.020.000,- dengan kisaran Rp 23.250.000,sampai Rp 35.550.000,-. 
Tabel 5. Biaya Tetap yang Dikeluarkan Oleh Ponggawa Perkapal Pada Usaha Perikanan Teripang di Pulau Barrang Lompo, 2011.

Table 5. Fixed Cost Incurred By Ponggawa in The Sea Cucumber (Holothuria Scabra) Business at Barrang Lompo Island, 2011.

\begin{tabular}{cc}
$\begin{array}{c}\text { Responden/ } \\
\text { Respondent }\end{array}$ & $\begin{array}{c}\text { Total Biaya Tetap (Ribu Rupiah)/ } \\
\text { Total Fixed Cost (Thousands of IDR) }\end{array}$ \\
\hline 1 & 35,550 \\
3 & 33,350 \\
4 & 34,050 \\
5 & 34,110 \\
6 & 23,750 \\
7 & 23,250 \\
8 & 23,750 \\
\hline Jumlah/Total & 24,350 \\
\hline Rata-rata/Average & $\mathbf{2 3 2 , 1 6 0}$ \\
\hline Kisaran/Range & $\mathbf{2 9 , 0 2 0}$ \\
\hline
\end{tabular}

Sumber : Data primer setelah diolah (2011)/Source : Primary data processed (2011)

\section{Pola hubungan kerja}

Dinamika hubungan kerja antara ponggawa dengan sawi telah berlangsung cukup lama sejak kegiatan penangkapan berlangsung. Bahkan dapat dikatakan seumur dengan kegiatan usaha perikanan tangkap, yang fungsi dan peranannya terus berkembang sesuai dengan perkembangan jenis dan kebutuhan penangkapan. Menurut Lampe (2003), kelompok ponggawa sawi yang disamping mengatur pembagian dan menyerap tenaga kerja, juga sekaligus berperan sebagai lembaga perolehan modal, pasar, penyelesaian urusan utang piutang, menetapkan aturan bagi hasil dan sebagai wadah sosialisasi kelompok dan jaminan-jaminan sosial ekonomi nelayan.

Pola hubungan kerja antara ponggawa sawi pada usaha telah mengalami perubahan penting dari bentuk hubungan patrón-klien lama bersifat ketat dan tertutup ke bentuk yang longgar dan terbuka. Ponggawa memberikan pelayanan ekonomi, sosial, perlindungan, pengetahuan, keterampilan kerja bahkan pandangan dan etos kerja. Sementara sawi memberikan pengabdian, ketaatan dan kepatuhan, kesetiaan, pengakuan, kepercayaan, kerja keras, disiplin dan tanggung jawab.

Pola hubungan kerja ponggawa sawi pada usaha perikanan pada dasarnya ada 2 jenis, yaitu berdasarkan suku dan kontrak kerja. Pola hubungan kerja berdasarkan suku yaitu pola menunjukkan adanya kesamaan suku/hubungan kekerabatan antara ponggawa dengan sawi. Contohnya adalah suku Bugis Makassar masih mempergunakan pola hubungan kerja berdasarkan pertimbangan suku dalam menjalankan usaha perikanan teripang. Pada pola kontrak kerja, kesamaan suku/hubungsn kekerabatan bukan pertimbangan utama dalam menjalin hubungan kerja, tetapi yang utama motivasi dan kemampuan kerja sawei. Hal ini menyebabkan lahirnya pola hubungan berdasarkan kontrak kerja. Dalam pola pertamani, ada kesepakatan kontrak kereja yang dituangkan dalam bentuk perjanjian/kontrak tertulis. Pada usaha perikanan teripang di Pulau Barrang Lompo, telah terjadi pergeseran pola hubungan kerja, awalnya berdarkan hubungan kekekrabatan/ kesamaan suku bergeser ke pola hubungan berdasarkan kontrak kerja.

Ponggawa dalam menjalankan usaha perikanan teripang memerlukan modal yang akan digunakan untuk membeli sarana penangkapan teripang dan membantu kebutuhan ekonomi sawi dan keluarganya. Sumber modal ponggawa di pulau Barrang Lompo ada dua, yaitu sumber modal internal, yaitu modal mandiri dan sumber modal eksternal yang sebagian modalnya merupakan investasi orang Cina. Hal ini akan berpengaruh pada investasi sarana penangkapan, pola operasi penangkapan, sistem bagi hasil dan pendapatan yang diperoleh ponggawa dan sawi. Pada pola pertama, ponggawa tidak terikat kepada seseorang sebagai tempat menjual teripang 
sehingga ponggawa bisa memilih pembeli yang menawarkan harga yang paling tinggi. Pada pola ke dua, ponggawa harus menjual seluruh hasil tangkapan teripang kepada orang Cina yang menginvestasikan modalnya dan harga pembelian ditentukan oleh orang Cina. Hal tersebut diterima ponggawa sebagai konsekuensi, walaupun harga yang ditawarkan pembeli lain lebih tinggi. Selama ini, responden ponggawa lebih memilih menerima investasi modal dari orang Cina daripada meminjam tambahan modal dari lembaga permodalan formal seperti bank dan koperasi. Hal ini disebabkan umumnya ponggawa telah menjalin hubungan kerja dengan orang Cina sejak lama, bahkan telah dijalankan secara turun-temurun dan sifat hubungan tidak ketat. Pada hubungan ini, ponggawa tidak dibebankan bunga karena sifatnya bukan pinjaman dan tidak ada batas waktu pengembalian modal. Cara pengembalian investasi yaitu langsung dipotong dari hasil penjualan teripang. Pola hubungan kerja antara ponggawa dengan orang Cina lebih mengutamakan motif ekonomi, dalam hal ini orientasi keuntungan lebih diutamakan. Pada pola hubungan II, sawi tidak berhubungan langsung dengan orang Cina, tetapi memperoleh dampak dari hubungan ponggawa dengan orang Cina, yaitu mempengaruhi sistem bagi hasil dan pendapatan yang diperoleh.

Kekuatan modal ponggawa mempengaruhi ketergantungan sawi pada ponggawa. Dalam arti, besarnya kepemilikan modal akan menggambarkan status ponggawa tersebut sebagai tempat yang cocok untuk dijadikan sebagai dasar menjalin hubungan kerja oleh para sawi. Oleh karena itu, harus diakui bahwa apabila kepemilikan modal kecil, maka lambat laun ponggawa akan ditinggalkan oleh para sawinya. Ponggawa harus berusaha semaksimal mungkin untuk memenuhi kebutuhan semua sawinya agar tidak pindah ke ponggawa lain. Kondisi tersebut menuntut para ponggawa untuk selalu menyediakan dana untuk pinjaman bagi para sawinya karena sewaktu-waktu sawi akan datang ke ponggawa untuk meminta panjar sebelum pergi melakukan operasi penangkapan teripang untuk keluarga yang ditinggalkan atau pinjaman uang untuk kegiatan sosial keluarganya. Hal ini juga merupakan salah satu cara ponggawa untuk mengikat sawinya sehingga bisa terus menjalin hubungan kerja dengan ponggawa.

Sawi hanya terikat kerjasama jika masih memiliki utang kepada ponggawa. Jika sawi sudah mampu melunasinya atau ada ponggawa lain yang sanggup membantu melunasi utangnya, maka sawi tersebut bisa pindah dari ponggawa sebelumnya dan secara langsung akan terikat hubungan kerja dengan ponggawa yang telah membayarkan utangnya. Hal ini mengindikasikan bahwa pola hubungan kerja ponggawa sawi semakin longgar dan terbuka. Hal ini sesuai dengan hasil penelitian Sutarni (2006) yang menyatakan bahwa bentuk hubungan ponggawa sawi telah mengalami perubahan penting dari hubungan patron-klien lama bersifat ketat dan tertutup ke bentuk yang longgar dan terbuka.

Hasil penelitian di Pulau Barrang Lompo, menunjukkan bahwa perekrutan sawi dapat terjadi secara timbal balik, yakni sawi yang mencari ponggawa atau sebaliknya ponggawa yang mencari sawi. Hubungan kerja ponggawa sawi disertai kesepakatan atau perjanjian kerja tidak tertulis yang disepakati oleh keduanya. Pola hubungan kerja ponggawa sawi sangat dipengaruhi oleh awal terbentuknya hubungan. Terbentuknya hubungan menghasilkan hak dan tanggung jawab masingmasing. Proses awal hubungan kerja terjadi setelah perjanjian kerja tidak tertulis antara ponggawa dengan sawi disepakati. Suatu perjanjian dimana pihak sawi mengikatkan dirinya untuk bekerja pada ponggawa dengan kesepakatan-kesepakatan tertentu yang telah disepakati bersama. Perjanjian kerja ini tidak tertulis disebabkan karena adanya sifat saling percaya antara ponggawa dan sawi.

Pola perjanjian kerja ponggawa sawi pada usaha perikanan teripang di Pulau Barrang Lompo ada 2 yang perbedaannya terletak pada sistem bagi hasil.. Pada perjanjian kerja pola pertama, ponggawa sebagai pemilik usaha berperan sebagai manajer, yaitu mengorganisasikan keseluruhan kegiatan produksi, menyediakan sarana penangkapan teripang yang selanjutnya dioperasikan oleh sawi. Pada sistem bagi hasil, setelah pendapatan kotor dikurangi biaya operasional penangkapan, kapal atau dalam hal ini ponggawa mendapatkan bagian 25\%. Ponggawa memperoleh bagian $25 \%$ karena dia yang memiliki sarana penangkapan dan resiko kerusakan kapal dan peralatannya menjadi tanggungan ponggawa. Sisanya $75 \%$ kemudian dibagi sesama sawi yang besarnya berdasarkan peran yang telah dilakukan pada operasi penangkapakan teripang. Jadi pendapatan yang diterima sawi berdasarkan sistem bagi hasil tidak sama. Khusus juragan laut, akan mendapat tambahan pendapatan 1\% dari bagian yang diterima ponggawa. Sawi akan 
dibayar oleh ponggawa setelah hasil tangkapan dijual. Pola perjanjian kerja I umumnya dijalankan oleh hubungan kerja ponggawa sawi yang sumber modal ponggawa merupakan modal mandiri.

Perjanjian kerja pola ke dua ponggawa sawi pada dasarnya sama dengan perjanjian kerja pola pertama, perbedaannya hanya terletak pada sistem bagi hasil antara ponggawa dengan sawi. Pada perjanjian kerja pola ke dua, bagian yang diperoleh ponggawa lebih banyak daripada pola hubungan kerja I. Pola perjanjian kerja II umumnya dijalankan oleh hubungan kerja ponggawa sawi yang sumber modal ponggawa sebagian berasal dari pinjaman orang cina.

Sawi di Pulau Barrang Lompo dalam melakukan aktifitas penangkapan teripang umumnya hanya memiliki kemampuan menyelam bagi penyelam teripang, keahlian mesin untuk bas/ masinis sedangkan untuk bagian selang dan koki tidak terlalu memerlukan keahlian khusus. Bagi juragan laut biasanya mereka harus memiliki jiwa kepemimpinan karenajuga berperan sebagai kapten kapal sekaligus penentu lokasi penangkapan dan lama operasi penangkapan teripang.

Operasi penangkapan teripang telah lama dijalankan oleh sawi di pulau Barrang Lompo. Berdasarkan hasil penelitian di Pulau Barrang Lompo, diketahui bahwa ada 2 pola operasi penangkapan yang dilakukan oleh responden, yaitu pada pola pertama, operasi penangkapan teripang dilakukan sepanjang tahun dan pada pola ke dua, operasi penangkapan teripang tidak dilakukan sepanjang tahun. Pola operasi penangkapan I umumnya dijalankan oleh etnik Bajo sedangkan pola ke dua dijalankan oleh etnik Bugis Makassar. Pola operasi penangkapan mempengaruhi sistem bagi hasil yang disepakati antara ponggawa dan sawi. Pada pola operasi penangkapan I, sistem bagi hasil yang disepakati adalah $25: 75$ sedangkan pada pola operasi penangkapan teripang yang kedua, sistem bagi hasil yang disepakati adalah $50: 50$.

Distribusi responden berdasarkan pola penangkapan teripang pada usaha perikanan teripang di pulau Barrang Lompo menunjukkan responden sawi yang melakukan operasi penangkapan teripang sepanjang tahun di tiga lokasi sebanyak 26 orang, yaitu $57,78 \%$ dan yang tidak melakukan operasi penangkapan teripang sepanjang tahun sebanyak 19 orang, yaitu $42,22 \%$.
Pada pola pertama operasi penangkapan teripang dilakukan sepanjang tahun. Pada bulan September sampai bulan Februari operasi penangkapan berlokasi di perairan Balikpapan sebanyak 3 trip selama kurang lebih 1 sampai 2 bulan per trip, jadi sekitar 3 trip per tahun. Pada bulan Maret sampai bulan Mei operasi penangkapan berlokasi di perairan Banjarmasin sebanyak 1 trip selama kurang lebih 1 sampai 3 bulan per trip, jadi sekitar 1 trip per tahun. Pada bulan Juni sampai bulan Agustus operasi penangkapan berlokasi di perairan Mamuju sebanyak 2 trip selama kurang lebih 1 bulan per trip, jadi sekitar 2 trip per tahun. Total trip per tahun sekitar 6 trip. Setelah pulang dari operasi penangkapan, mereka biasanya hanya tinggal sekitar satu minggu di pulau. Waktu luang ini umumnya digunakan untuk beristirahat sambil berkumpul dengan keluarga, mempersiapkan kebutuhan operasional operasi penangkapan berikutnya, mengecek kondisi kapal dan peralatan dan sekaligus menunggu upah dari ponggawa berdasarkan sistem bagi hasil yang telah disepakati sebelumnya.

Pada pola kedua, operasi penangkapan teripang tidak dilakukan sepanjang tahun. Pada bulan September sampai bulan Februari operasi penangkapan berlokasi di perairan Balikpapan sebanyak 3 trip selama kurang lebih 1 sampai 2 bulan per trip, jadi sekitar 3 trip per tahun. Pada bulan Maret sampai bulan Mei operasi penangkapan berlokasi di perairan Banjarmasin sebanyak 1 trip selama kurang lebih 1 sampai 3 bulan per trip, jadi sekitar 1 trip per tahun. Pada bulan Juni sampai bulan Agustus responden istirahat karena cuaca pada bulan ini tidak menentu sehingga sangat beresiko melakukan penangkapan. Jadi, total trip per tahun sekitar 4 trip. Waktu luang ini umumnya pergunakan untuk berkumpul bersama keluarga, memperbaiki perahu dan peralatan penangkapan yang rusak dan sebagian juga di antara mereka mempergunakan waktu luangnya dengan menjadi nelayan perorangan untuk memperoleh penghasilan guna memenuhi kebutuhan hidup keluarganya dengan lokasi penangkapan di sekitar pulau Barrang Lompo.

Terbentuknya dua pola operasi penangkapan dipengaruhi oleh sumber dan jumlah modal yang dimiliki oleh ponggawa. Pada pola pertama, sumber modal ponggawa merupakan modal mandiri sehingga mereka bisa menginvestasikan modalnya untuk membeli sarana penangkapan teripang yang memiliki ukuran dan daya muat 
yang memungkinkan bisa melakukan operasi penangkapan teripang sepanjang tahun. Pada pola ke dua, sumber modal pongawa sebagian merupakan investasi orang Cina sehingga mereka memiliki beban harus mengembalikan investasi tersebut. Untuk mengurangi pengeluaran, maka mereka menginvestasikan modalnya untuk membeli sarana penangkapan teripang yang ukurannya relatif kecil sehingga beresiko untuk melakukan penangkapan pada saat keadaan laut tidak menentu.

\section{Pemasaran}

Pemasaran hasil tangkapan teripang dilakukan oleh ponggawa. Berdasarkan hasil penelitian, diketahui bahwa ada 2 pola pemasaran hasil tangkapan teripang yang dijalankan oleh ponggawa. Pola pemasaran hasil tangkapan teripang dipengaruhi oleh sumber modal ponggawa. Pada pola pertama, ponggawa tidak terikat pada seseorang sebagai tempat memasarkan teripang. Tetapi mereka bebas menjual teripang hasil tangkapan kepada pembeli yang menawarkan harga yang paling tinggi. Umumnya, responden ponggawa yang menjalankan pola pertama menjual teripangnya kepada eksportir di Surabaya karena menawarkan harga yang lebih tinggi dibandingkan dengan pedagang pengumpul yang ada di Makassar. Selisih harga teripang di Makassar dengan Surabaya sekitar 5 sampai $10 \%$. Pada pola ke dua, ponggawa harus menjual seluruh teripangnya kepada orang Cina yang menginvestasikan modalnya kepada ponggawa. Umumnya harga pembelian dari orang Cina lebih rendah sekitar $20 \%$ dari harga standar yang berlaku di pasaran.

Berdasarkan hasil penelitian diketahui bahwa harga teripang bervariasi menurut jenis dan ukurannya. Jenis teripang yang memiliki harga yang tinggi adalah jenis Teripang Koro dan Teripang Biba. Hal ini disebabkab jenis teripang tersebut memiliki permintaan yang tinggi di pasaran. Harga teripang juga dipengaruhi oleh kualitas teripang hasil tangkapan.

\section{Penerimaan dan Pendapatan}

Penerimaan usaha perikanan teripang bervariasi karena dipengaruhi oleh hasil tangkapan dan harga jual teripang. Rata-rata penerimaan per trip berdasarkan lokasi penangkapan adalah pada pola operasi penangkapan pertama, penerimaan rata-rata yang terbesar per trip diperoleh dari perairan Banjarmasin dengan rata-rata sekitar Rp. 63.750.000,- dan kisaran Rp. 60.000.000,sampai Rp. 70.000.000,-. Pada pola operasi penangkapan II, hasil tangkapan teripang rata-rata terbesar per trip juga diperoleh perairan Banjarmasin dengan penerimaan rata-rata per trip sekitar Rp. 48.000.000,- dan kisraan Rp. 45.000.000,sampai Rp. 50.000.000,-. Apabila dibandingkan, penerimaan yang diperoleh pada pola pertama lebih banyak dibandingkan pola ke dua, Hal ini dipengaruhi oleh jenis, jumlah dan harga teripang hasil tangkapan.

Rata-rata penerimaan per tahun usaha perikanan teripang di pulau Barrang Lompo berdasarkan lokasi penangkapan menunjukkan pada pola operasi penangkapan I, penerimaan rata-rata yang terbesar per tahun diperoleh dari perairan Balikpapan dengan rata-rata sekitar Rp. 161.250.000,- dan kisaran Rp. 150.000.000,sampai Rp. 180.000.000,-. Pada pola operasi penangkapan II, hasil tangkapan teripang rata-rata terbesar per trip juga diperoleh perairan Balikpapan dengan penerimaan rata-rata per tahun sekitar Rp. 120.000.000,- dan kisaran Rp. 105.000.000,- sampai Rp. 135.000.000,-.

Berdasarkan hasil penelitian diketahui bahwa pendapatan yang diperoleh ponggawa dan sawi jumlahnya tidak tetap, tergantung dari jumlah, jenis dan harga teripang yang ditangkap sehingga mempengaruhi hasil sistem bagi hasil. Pendapatan ponggawa dan sawi tidak bisa diprediksi karena tergantung dari hasil tangkapan yang sifatnya juga tidak menentu. Adanya ketidakpastian hasil tangkapan inilah yang mendorong sawi untuk melakukan hubungan kerja dengan ponggawa.

Sistem bagi hasil merupakan alternatif yang dikembangkan rata-rata masyarakat nelayan untuk mengurangi resiko. Sistem bagi hasil dapat mengurangi resiko bagi ponggawa sebagai pemilik kapal dan meningkatkan motivasi kerja sawi. Hal ini terjadi karena hasil tangkapan yang tidak dapat ditentukan kepastiannya. Terbentuknya sistem bagi hasil dipengaruhi oleh adanya perubahan hubungan kerja ponggawa sawi. Perubahan ini disebabkan semakin terbukanya informasi bahwa sumberdaya pesisir selain untuk dikonsumsi, juga memiliki nilai ekonomi di pasaran. Hal ini mendorong semakin banyak ponggawa yang memasuki daerah pesisir dengan tujuan yang sama dan pada akhirnya terjadi eksploitasi 
besar-besaran terhadap sumberdaya pesisir yang mengakibatkan terjadinya over fishing. Sistem bagi hasil inilah yang merubah orientasi hubungan kerja ponggawa sawi dari orientasi sosial menjadi orientasi ekonomi.

Sistem bagi hasil yang diterapkan pada usaha perikanan teripang di lokasi penelitian ada 2 pola berdasarkan hasil wawancara yang dilakukan dengan beberapa responden ponggawa dan sawi. Hal ini dipengaruhi pola hubungan kerja yang dijalankan antara ponggawa dengan sawi. Pada pola hubungan kerja yang menerapkan gabungan antara suku dan kontrak kerja atau pola pertama, menetapkan sistem bagi hasil $25: 75$, sedangkan pola hubungan kerja yang masih menerapkan hubungan suku atau pola pertama, menetapkan sistem bagi hasil $50: 50$. Hal ini disebabkan pada pola pertama, motif ekonomi lebih diutamakan daripada motif sosial sedangkan pada pola pertama motif sosial masih dipertimbangkan. Jadi telah terjadi perubahan sistem bagi hasil pada usaha perikanan teripang di pulau Barrrang Lompo, Dahulu sistem bagi hasil yang diterapkan umumnya $50: 50$, tetapi sekarang telah bergeser ke sistem bagi hasil $25: 75$.

Sistem bagi hasil disepakati pada saat melakukan perjanjian hubungan kerja antara ponggawa dengan sawi dan umumnya termasuk salah satu isi perjanjian. Sistem bagi hasil yang berlaku tidak sama untuk semua ponggawa. Pola sistem bagi hasil antara ponggawa dengan sawi usaha perikanan teripang di pulau Barrang Lompo menunjukkan ada dua pola sistem bagi hasil pada usaha perikanan di lokasi penelitian. Pola pertama adalah $25: 75$, yaitu ponggawa mendapatkan bagian $25 \%$ dan $75 \%$ sisanya dibagi kepada sawi berdasarkan perannya dalam operasi penangkapan teripang, sedangkan pola ke dua yaitu $50: 50$, dimana ponggawa mendapatkan bagian $50 \%$ dan $50 \%$ sisanya dibagi kepada sawi berdasarkan perannya dalam operasi penangkapan teripang.

Jumlah bagian yang diperoleh sawi berbeda menurut perannya pada saat operasi penangkapan teripang. Khusus untuk juragan laut, memperoleh tambahan bagian $1 \%$ dari bagian ponggawa. Sistem bagi hasil pola pertama memunjukkan bahwa telah terjadi perubahan sistem bagi hasil pada hubungan kerja ponggawa sawi. Pada awalnya, sistem bagi hasil yang diterapkan antara ponggawa dengan sawi adalah $50: 50$. Sistem bagi hasil ini berbeda dengan sistem bagi hasil yang ditemukan oleh peneliti sebelumnya. Berdasarkan hasil penelitian sebelumnya yang dilakukan oleh Sutarni (2006) diketahui bahwa sistem bagi hasil antara ponggawa dengan sawi di Kabupaten Sinjai adalah $75: 25$, yaitu ponggawa memperoleh $75 \%$ dan $25 \%$ dibagi oleh sejumlah sawi. Hasil penelitian Nadjib (1998) menunjukkan pola umum bagi hasil di daerah Teluk Lampung dan Pasuruan adalah pemilik memperoleh bagian 50\% dari hasil bersih tangkapan ditambah 15\% dari jumlah kotor hasil tangkapan sebagai cadangan jika ada kerusakan kapal ataupun jaring.

Khusus untuk juragan laut, memperoleh bagian 30\% dari bagian ponggawa dan Rp. 5000,tiap kilogram teripang hasil tangkapan. Sistem bagi hasil yang disepakati umumnya hanya merupakan dasar pembagian hasil. Apabila hasil yang diperoleh banyak, maka ponggawa akan memberikan tambahan pendapatan kepada sawi. Tambahan ini kemudian dikenal dengan istilah bonus.

Pendapatan rata-rata per bulan yang diperoleh responden ponggawa pada usaha perikanan teripang di pulau Barrang Lompo menunjukkan pada sistem bagi hasil pola pertama, yaitu $25: 75$, pendapatan rata-rata per bulan ponggawa sekitar Rp. 3.850.000,- dengan kisaran Rp. 3.300.000,-sampai Rp.4.500.000,-, sedangkan, pendapatan rata-rata per bulan sawi sekitar Rp. 1.080.000,- dengan kisaran Rp. 850.000,sampai Rp. 1.375.000,-. Pada sistem bagi hasil pola ke dua, yaitu $50: 50$, pendapatan rata-rata per bulan ponggawa sekitar Rp. 2.550.000,dengan kisaran Rp. 2.100.000,- sampai Rp. 2.980.000,-, sedangkan pendapatan rata-rata per bulan sawi sekitar Rp. 573.000,- dengan kisaran Rp. 480.000,-- sampai Rp. 650.000,-. Pendapatan rata-rata per bulan yang diterima ponggawa dan sawi dipengaruhi oleh sumber modal ponggawa, pola operasi penangkapan dan sistem bagi hasil.

Pendapatan yang diperoleh ponggawa dan sawi berdasarkan sistem bagi hasil yang disepakati, baik pola 25:75 maupun pola 50:50, masih menunjukkan ketimpangan. Hal ini disebabkan bagian yang diterima sawi berdasarkan sistem bagi hasil harus dibagi lagi berdasarkan jumlah sawi. Berdasarkan hasil analisis, pendapatan yang diperoleh sawi di atas standar upah minimum regional Sulawesi Selatan tahun 2010, yaitu Rp650.000,-. Sedangkan pada pola sistem bagi hasil II, pendapatan yang diterima sawi masih di bawah standar upah minimum regional Sulawesi Selatan. 
Berdasarkan pengamatan dan hasil wawancara selama penelitian, diketahui bahwa faktor yang menyebabkan terjadinya kesenjangan ekonomi antara ponggawa dengan sawi adalah ketimpangan dalam sistem bagi hasil, selain itu pengaruh yang lain adalah rendahnya pengetahuan manajemen keuangan sawi. Jadi, walaupun pendapatan rata-rata yang diterima sawi pada sistem bagi hasil pola pertama sudah di atas standar upah minimum regional, akan tetapi umumnya mereka masih sulit keluar dari kemiskinan.

Apabila sawi mendapatkan pendapatan, maka umumnya tidak langsung membayar panjar yang telah diambil sebelum melakukan operasi penangkapan, tetapi digunakan untuk membeli barang-barang konsumtif. Hal ini umumnya terjadi pada sawi yang masih bujangan sehingga lama-kelamaan utangnya kepada ponggawa semakin menumpuk dan ditambah lagi kalau operasi penangkapan mengalami kerugian, secara otomatis utangnya semakin bertambah. Setelah berkeluarga, kebutuhan mereka semakin meningkat dan di satu sisi mereka juga harus membayar utangnya kepada ponggawa. Selain itu, permohonan pinjaman untuk kebutuhan sosial seperti pernikahan dan membiayai keluarga yang sakit semakin menambah jumlah utang sawi kepada ponggawa. Hal inilah yang menyebabkan para sawi sulit untuk keluar dari kemiskinan.

Institusi ponggawa sawi pada usaha perikanan teripang di pulau Barrang Lompo, tata hubungannya mengacu pada tradisi yang ada dan telah dilakukan secara turun-temurun sehingga akan terus berkelanjutan sampai masa yang akan datang selama komoditas teripang masih bisa diperoleh dari perairan. Keberlanjutan hubungan ini juga dipengaruhi oleh tingkat pendidikan dan cara berpikir sawi. Hal ini disebabkan selama ini sawi terkendala pada modal untuk membeli sarana penangkapan teripang dan ponggawa bisa menangani kendala ini dengan jalan mempekerjakan sawi sebagai tenaga kerja pada sarana penangkapan teripangnya. Selain itu, sawi rata-rata tidak memiliki keahlian lain selain meyelam dan tingkat pendidikannya sebagian besar masih rendah. Di satu sisi, pendapatan yang mereka peroleh dari penangkapan teripang sangat menggiurkan sehingga anak-anak yang seharusnya masih sekolah lebih memilih menjadi sawi dan hal ini didukung oleh orang tua mereka.

\section{KESIMPULAN DAN IMPLIKASI KEBIJAKAN}

Berdasarkan hasil penelitian dan pembahasan yang telah diuraikan, maka dapat disimpulkan :

1. Pola hubungan kerja ponggawa sawi pada usaha perikanan teripang di Pulau Barrang Lompo terdiri dari 2 pola berdasarkan suku/ hubungan kekerabatan dan kontrak kerja

2. Sistem bagi hasil antara ponggawa dan sawi pada usaha perikanan teripang di pulau Barrang Lompo ada 2 pola, yaitu pola pertama ponggawa mendapat bagian 25 persen dari hasil setelah dikurangi biaya operasional dan 75 persen sisanya dibagikan kepada sawi, sedangkan pada pola ke dua ponggawa mendapat bagian 50 persen dari hasil setelah dikurangi biaya operasional dan 50 persen sisanya dibagikan kepada sawi

3. Pendapatan rata-rata per bulan yang diterima ponggawa dan sawi pada sistem bagi hasil 25 : 75 berkisar Rp. 3.300.000,- sampai Rp. 4.500.000,dan berkisar Rp. 750.000,- sampai Rp. 1.375.000,- untuk sawi. Pada sistem bagi hasil $50: 50$, pendapatan rata-rata per bulan yang diterima ponggawa berkisar Rp. 2.100.000,- sampai Rp. 2.980.000,- untuk ponggawa dan berkisar Rp. 480.000 ,- sampai 1.650.000,- untuk sawi.

\section{IMPLIKASI KEBIJAKAN}

1. Sebaiknya ada lembaga pemberi pinjaman untuk nelayan, khususnya sawi yang bersifat lebih fleksibel, baik dalam administrasi, agunan maupun angsuran sehingga mereka bisa menjadi nelayan mandiri tanpa terikat lagi dengan ponggawa.

2. Perlu dditingkatkan lagi penyuluhan tentang bahaya dekompressi agar bisa meminimalisir jumlah penyelam/sawi yang terkena dekompressi dan bisa menggugah ponggawa untuk mengganti kompressor dengan tabung selam yang lebih aman.

\section{DAFTAR PUSTAKA}

BPS Barrang Lompo. 2010. Baranglompo dalam Angka Tahun 2010. Makassar.

Indar, Y.N. 2005. Sistem Sosial dan Kelembagaan Tradisional Masyarakat dalam Pengelolaan Pesisir dan Laut. Makalah disajikan dalam 
Training on Integrated Coastal Zone Management (ICZM). MCRMP Bappeda Gorontalo. Gorontalo 10-19 Agustus 2005.

. 2003. Budaya Bahari dalam Konteks Global dan Modern. Makalah disajikan dalam Kongres Kebudayaan V. Bukit Tinggi. Bukittinggi 20-23 Oktober 2003.

Lampe. 2003. Budaya Bahari dalam Konteks Global dan Modern. Makalah disajikan dalam Kongres Kebudayaan V. Bukit Tinggi. Bukittinggi 20-23 Oktober 2003.
Nasution, S. 2004. Metode Research. PT. Bumi Askara. Jakarta.

Sallatang, M.A. 1982. Ponggawa-Sawi : Suatu Studi Kelompok Kecil. Disertasi tidak diterbitkan. Unhas. Makassar.

Sugiyono. 2008. Metode Penelitian Kuantitatif, Kualitatif, $R \cap D$. PT. Alvabeta. Bandung.

Sutarni. 2006. Prilaku Kewirausahaan Ponggawa: Studi Kasus Unit Bagang di KeLurahan Lappa Kabupaten Sinjai. Tesis tidak dipublikasikan. Universitas Hasanuddin. Makassar. 